532.528.001.57 :629.12.037 : 620.193.16(492)

[96]オランダ国立船舶試験所の大形キャビテーシ ョン水そうの大改造 [J.H. Witte \& J. Esveldt, International Shipbldg. Progress, 1966-10, Vol. 13, No. 146 , p. 326〜 335, 図 18] この水そうは, 90 $\mathrm{cm} \times 90 \mathrm{~cm}$ 测定部断面, 最大流速 $11 \mathrm{~m} / \mathrm{s}$, 駆動モータ 出力 300 Pの典型的なゲッチンゲン形プロペラ用回流 キャビテーション水そうであったが，1957年以後三次 にわたる大改造により, 最大流速の増大（最低キャビ テーション係数が 0.42 から 0.30 に下がる), 騒音の 軽減（約 $30 \mathrm{~dB}$ も軽減され，かつ騒音特性の詳細も求 められた）に成功し，ついで，水そう内静仼の自動制 御, 動力測定装置あるいは動力制御装置の近代化も行 なわれた。

流体力学的改良のおもなるものは，（i）測定部直後 の曲管を, 従来の二又曲管（かなりのキャビテーショ ン発生になやまされていた）を単一の低損失耐キャビ テーション性の曲管に変更，（ii）ポンプ羽根車をキャ ビテーションあるいは Singing のおきないものに交 換,（iii）プロペラ支持棒の断面形状の改良，（iv）ポ ンプ入口側八ネカム部流路形状の改良などである.

また，観測用空は従来のものの約 2 倍の十分に大き なものとし, 高速写真撮影もより容易となった（この 改造に際し，测定部強度の低下を防止するために，測 定部断面を従来のほぼ四角形より正八角形に変更した が，測定部流速分布の一様性は十分良好なものであっ た).

[大場利三郎]

\section{$532.542: 621.643$}

※[97]管路における乱れの伝ぱ [J.S. Ansari \& R. Oldenburger, Trans. ASME, Ser. D, 1967-6, Vol. 89, No. 2, p. 415 422, 図 10] この論文の目的は 外乱が管路の流体中を進むとき，その減衰と分散，す なわちパルスの振幅の減小と幅の増加の現象を研究す ることである.

管路中の流体の運動方程式と連続の式から粘性を考 慮した波動方程式を遒き，その解としてある波動の式 を仮定し，この系のもつ条件加ら近似的にこの解の形 を決定している.これによって流体のもつ粘性の影響 が $e^{-k t}$ の形の減衰として表わされることがわかる.

この近似解を用いて長方形波状速度の入力に対する 厳密解をラプラス変換によって求めてある。をた管端 壁の運動と管の膨張収縮を考慮に入れて, 波の自由可 動端壁での反射を解析している。

剛体の管路中の非粘性流体では減衰や分散は起こら ないが，粘性流体ではそれらが見られる．管路の閉じ た自由端壁からの波の反射は減衰や分散を引き起こ 寸. 管摩擦係数の十分小さい值に対しては, 粘性の影 響は分散には無関係に純粋に $e^{k t}$ の形の減衰によって 近似できることがわかる。

[韦川，常雄]

\section{$532.55: 621.643: 678.049$}

[98]微量のポリマ粉末を液中に添加することによ る流体摩擦損失の軽減 [A. White, J. Mech. Engng. Sci., 1966-12, Vol. 8, No. 4, p. 452 455, 図 3]

「数 ppm (重量) の極微量のポリマ添加により, 流 体摩擦抗力が $50 \%$ 以上も軽減する」という実験的事 実(1) (3) には，将来多くの応用も考えられ，興味がも たれよう.この報告では, Guar gum ポリマを使用し
ての組織的な管摩擦損失の測定から，上記の効果を実 証し，さらにレイノルズ数が大なるほど，また管径が 小なるほど，この効果が大になることを示している. ついで, この効果の機構を追及し，この効果は添加ポ リマによる乱流乱れの抑止作用の結果として現われる こと, さらにこの効果は, 限界壁摩擦係数 $\tau_{w}=0.05$ $\mathrm{lb} / \mathrm{ft}^{2}$ (この值は管径 $d$, ポリマ濃度に無関係に一 定), したがって，最小レイノルズ数 $R_{e}$ onset（これ は $d^{8 / 7}$ に比例して変わり，最小值は約 $3000 ）$ 以上で 認められ，この $R_{e}$ onset 以下では，ポリマを含有し てもニュートン流体とみなし得ることも示した.

なお,ここに使用した Guar gun は従来使用され た Polyacrylamide あるいは Polyethylen に比し, はるかに安定な効果を示すとも述べている.

(1) J.W. Hoyt \& A.G. Fabula, 19645 th Symp. on Naval Hydrodyn, Bergen.

(2) G.E. Gadd, Nature, 206-4983 (1965), 463.

(3) C. Elata \& J. Tirosh, Israel Fl. Techn., 3 (1965). 1.

[大場利三郎]

$532.595 .2: 518.5: 681.14$

[99] 水力学的過渡現象 [V.L. Streeter \& E.B. Wylie, Hydraulic Transients, 1967, pp. 329, B 5 判, 5800 円, McGraw-HiII] 本書は, 管内の流速が急 変する際に生ずる水撃作用現象および定常運転時にお ける管路系の共振の問題を取扱っている.この二つの 問題を解く手段として, ディジタルコンピュータを用 いている点が，大きな特徴である.

まず，この二つの現象およびその基礎理論の概要を 説明した後, 簡単な系から順次複雑な系を取上げ, 水 撃作用の計算には特性曲線法を, 管路の固有振動・共 振の計算にはインピーダンス法を用いて, コンピュー タによる解法を述べている. 各章の末尾に練習問題 を，付録にコンピュータプログラムをのせているが， これは本書の実用価值をよりいっそう高めている。な お，開水路の過渡現象についてもふれている.

水撃作用の図式解法については, Bergeron の名著 および Parmakian の手ごろな入門書があるが，図式 解法では長い計算時間を要する複雑な管路系が多くな りつつある今日, コンピュータによる解法を述べた Streeter と Wylie の著書の発行は，まさに時宜を得 た企てということができよう。【宮代裕]

\subsection{8: 621.6.01}

[100]濃密度空気輸送に関する研究 [W. Rausch, Förd. u. Heben, 1966-12, Jg. 16, Ht. 12, S. 968 976, 図 2, 表 2]薄い密度の空気輸送の計算は種 々の方法があるが，濃い場合の計算はまだ知られてい ない.ここには Barth の理論を濃い場合にも適用で きるように拡張して（高压のため空気の圧縮性を考慮 する)実験と対比させ, 認容できることを示している.

$$
\begin{aligned}
& \Delta P_{L R}=P_{2}\left\{\left[1+\left(\frac{n+1}{n}\right) \lambda_{1} \frac{G_{M}^{2} \Delta l}{\mu^{2} F^{2} \gamma_{12} 2 d g P_{2}}\right]^{\frac{n}{n+1}}-1\right\} \\
& \Delta P_{Z B}=P_{2}\left\{\left[1+\left(\frac{n+1}{n}\right) \frac{G_{M}^{2} \Delta(c / v)}{g \mu F^{2} \gamma_{12} P_{2}}\right]^{\frac{n}{n+1}}-1\right\} \\
& \Delta P_{Z R}=P_{2}\left\{\left[1+\left(\frac{n+1}{n}\right) \lambda_{Z} \frac{G_{M} \Delta l}{\mu F^{2} 2 g \gamma_{12} d P_{2}}\right]^{\frac{n}{n+1}}-1\right\} \\
& \Delta P_{Z K r}=Z K \cdot \Delta P_{Z B} \\
& \Delta P_{L W}=\xi \frac{G_{M}^{2}}{\mu^{2} F^{2} \gamma 2 g}
\end{aligned}
$$

